https://www.sworldjournal.com/index.php/swj/article/view/swj08-03-008 DOI: 10.30888/2663-5712.2021-08-03-008

OPTIMIZATION OF HOLIATRY TREATMENT OF ACUTE INTESTINAL INFECTIONS: APPROACH WITH PROBIOTIC LACTO AND ORAL SOLUTION REO

\title{
ОПТИМИЗАЦИЯ КОМПЛЕКСНОГО ЛЕЧЕНИЯ ОСТРЫХ КИШЕЧНЫХ ИНФЕКЦИЙ: ПОДХОД С ПРИМЕНЕНИЕМ ПРОБИОТКА ЛАКТО И ПЕРОРАЛЬНЫМ РАСТВОРОМ РЕО
}

Sydorchuk A.S./ Сидорчук A.C. Bukovinian State Medical University, Chernivtsi, Ukraine Буковинский государственный медииинский университет

Bohachyk N.A./ Богачик H.A. Bukovinian State Medical University, Chernivtsi, Ukraine Буковинский государственный медицинский университет

Grubliak L.V./ Грубляк Л.В. Bacteriologic laboratory, Chernivtsi Municipal Clinical Hospital, Ukraine Бактериологическая лаборатория Областной клинической больниць

Venglovs'ka Y.V./ Венгловская Я.В.

Bukovinian State Medical University, Chernivtsi, Ukraine Буковинский государственный медииинский университет

\begin{abstract}
The article dedicated to the study of efficiency application of contemporary probiotic "Lacto" in the combination with oral solution Reo in the holiatry treatment of patients with acute intestinal infections. Clinical and microbiological efficiency of lacto is demonstrated as Saccharomyces contained probiotic, that could corrects the abnormal intestine microbiocenosis from the first days of acute intestinal disease, caused by different causative agents. Lacto and Reo can be recommended in the holiatry therapy in adult patients in the case of acute diarrhea syndrome.
\end{abstract}

Key words: acute intestinal infection, treatment, Saccharomyces, "Lacto", "Reo".

Introduction.

Nowadays the morbidity on acute intestinal infectious diseases in Europe and Ukraine is still high. The available data on the incidence of foodborne disease represent only the "tip of the iceberg"; the true number of cases is unknown. This gap is due to the limitations of surveillance systems [1].

Annually, more than 23 million people fall ill from eating contaminated food, resulting in 5000 deaths and more than 400000 disability-adjusted life years. The most frequent causes of foodborne disease are diarrhoeal disease agents. Noroviruses, Campylobacter spp., Non-typhoidal Salmonella spp. are responsible for the majority of deaths [3]. Among the foods that are more often a factor in the transmission of infection are milk, dairy products; fruits, vegetables; fish and fish products; confectionery, salads, juices, eggs [2].

Microorganisms that cause intestinal infections remain and continue to multiply in the body, and this contributes to the development of dysbiotic changes in the intestinal microbiocenosis. In addition, such a person becomes a source of infection for other people and family members. It is especially dangerous if such patient works at the enterprise of food, water supply, in children's preschool institution. It can be a source of disease for the whole team.

The incidence of acute intestinal diseases in Ukraine has a high proportion 
among 12-15 millions of registered infectious diseases. Risk of disease on the territory of the European Union and Ukraine is increasing in the summer-autumn season [4].

Normal intestinal microflora has a pronounced detoxifying effect on toxins of exogenous and endogenous origin due to their absorption and excretion, because acts as a "natural sorbent" [5]. In our previous study we defined clinical and microbiologica efficacy of combined pre- and probiotic as additional component of therapy patients with acute non-typhoidal salmonellosis, toxic food poisonings and shigellosis at Bykovyna, Western Ukraine, Eatern Euopean region group C by WHO grading [6].

The purpose of the research - to study the efficacy of the combination of probiotic "Lacto" and oral solution "Reo" in holiatry treatment of patients with acute intestinal infections - toxic food borne intoxications and acute gastroenteritis presumable infectious oetiology on the clinical course and intestinal microbiota.

\section{Material and methods.}

A prospective clinical microbiological research of "case-control" design was conducted in 2019-2020 on the basis of department of infectious diseases at Chernivtsi regional clinical hospital (Northern Bukovina, a region in Western Ukraine) with 18 patients with acute intestinal infections. The age of the patients ranged from 18 to 67 years, the gender distribution was equivalent to almost 1:1. Collection of material for dysbacteriosis were taken on the admission time and after treatment: faeces were delivered without preservative no later than 2 hours after selection. Stools were collected in sterile containers, Petri dishes in quantities up to $20 \mathrm{~g}$. The material was delivered to the microbiological laboratory of the regional clinical hospital, where a comprehensive microbiological study was performed. Saccharomyces boulardii as main component of Lacto had direct antagonism to Clostridium difficile, Clostridium pneumoniae, Staphylococcus aureus, Pseudomonas aeruginosa, Candida krusei, Candida pseudotropical, Candida albicans, Salmonella typhi, Salmonella enteritidis, Escherichia coli, Shigella dysenteriae, Shigella flexneri, Klebsiella, Proteus, Vibrio cholerae, as well as to Enthamoeba hystolitica, Lambliae, Enterovirus, rotaviruses.

Eighteen patients with moderate course of gastroenteritis were examined for food poisoning caused by opportunistic flora (Citrobacter, Proteus, pathogenic staphylococcus). Clinical and laboratory studies (general clinical and bacteriological) were performed. The course of gastroenteritis (with acute onset, short incubation period, short-term increase in body temperature to subfebrile level, nausea, vomiting, pain mainly in the epigastrium and paraumbilical area, loose stools without pathological admixtures up to 5-6 times per day).

Lacto is a combined product containing probiotic microorganisms of four types. Main properties of Lacto: have antidiarrheal (antisecretory) effect due to a decrease in c-AMP in enterocytes, which leads to a decrease in the secretion of water and sodium into the intestinal lumen; antimicrobial action due to the ability of Saccharomyces boulardii to inhibit the development of pathogenic and opportunistic bacteria and fungi that disrupt the intestinal biocenosis.

The use of the drug Lacto in combination with $\mathrm{ReO}$-water in acute intestinal 
diseases in the available references we have not found. Chemical composition of $\mathrm{ReO}$-solution / 1: $\bullet \mathrm{Na}+900 \mathrm{mg} / \mathrm{L} \cdot \mathrm{K}+160 \mathrm{mg} / 1 \cdot \mathrm{Mg} 2+50 \mathrm{mg} / 1 \cdot \mathrm{Ca} 2+50 \mathrm{mg}$ / $1 \mathrm{CL}-1600 \mathrm{mg} / 1 \cdot \mathrm{HCO} 3-300 \mathrm{mg} / 1 \cdot$ Sorbitol up to $90 \mathrm{mg} / 1 \cdot$ Carbon dioxide $0.05-0.3 \% \cdot$ Mineralization (mg / dm3): 2500-300. This oral solution recommended for conditions accompanied by dehydration and intoxication of the host. Due to the balanced of water-salt composition of $\mathrm{ReO}$ it provides the fastest absorption of water and electrolytes, and eliminates symptoms of dehydration (fatigue, headache, dry skin and mucous membranes), prevents dehydration, normalizes diuresis and reduces intoxication.

The study of intestinal microbiocenosis included the presence of pathogenic microflora, the total number of Escherichia coli, Escherichia coli with reduced enzymatic activity, opportunistic enterobacteria, staphylococci, fungi of the genus Candida, lactobacilli, bifidobacteria, haemolytic cocci. Changes in the microbiocenosis of the colon were found in all patients: a decrease in the number of lactobacilli, bifidobacteria, the total amount of E. coli. The content of lactobacilli $<10^{6} \mathrm{CFU} / \mathrm{g}$ of feces was observed in 6 patients and only one patient approached the norm of $10^{7} \mathrm{CFU} / \mathrm{g}$ (norm $>10^{6} \mathrm{CFU} / \mathrm{g}$ ); bifidobacteria was $<10^{7} \mathrm{CFU} / \mathrm{g}$ in 4 patients, and in 3 patients approached normal $\left(>10^{7} \mathrm{CFU} / \mathrm{g}\right)$. There was also a decrease in the total amount of E. coli $<10^{6} \mathrm{CFU} / \mathrm{g}$ in 6 people.

All patients received basic therapy - enterosorbents (enterosgel), enzymes, spasmolytics, antibacterial drugs (mainly norfloxacin and nifuroxazide). Patients of basic group were additionally prescribed Lacto one capsule three times a day for 30 minutes before eating, drinking a small amount of water for five days.

In patients who had received both Lacto and Reo in addition to standard therapy, faster previously disappeared symptoms of intoxication: fever and general weakness. Analysis of clinical manifestations of the gastrointestinal tract revealed a more pronounced effect obtained when using such a combination, which manifested a faster normalization of bowel movements, the disappearance of abdominal pain. According to the results of clinical and laboratory monitoring, it was found that in patients who received in combination treatment probiotic Lacto in combination with Reo oral solution improvement of general condition and normalization of bowel movements occurred earlier (on average by 1,2 days).

In our previous study dedicated to the improvement of treatment of patients with gastrointestinal salmonellosis, food borne toxic infections and shigellosis with lactoken, we suggested less clinical effect. Comparatively better clinical and bacteriological improvement with Lacto and Reo should be due to presence of special Saccharomyces boulardii and their local effect on intestinal microbiota.

\section{Conclusions:}

1. The appointment of the probiotic Lacto in combination with consumption of oral solution $\mathrm{ReO}$ to the basic therapy of patients with food poisoning leads to a more rapid disappearance of symptoms of intoxication and dyspeptic disorders.

2. There is microbiological efficacy of such scheme as was revealed the betterment of qualitative and quantitative content of autochthonous intestinal microflora of main group patients.

3. Practical recommendation: the use of lactulose-containing, bifidobacterium- 
containing, saccharomyces contained probiotic Lacto in combination with oral solution ReO may be recommended for inclusion in the standard therapy of food borne toxic infections as well as acute gastroenteritis of presumble infectious etiology.

\section{References}

1. Quinlan, Jennifer J. (2013) Foodborne Illness Incidence Rates and Food Safety Risks for Populations of Low Socioeconomic Status and Minority Race/Ethnicity: A Review of the Literature" Int. J. Environ. Res. Public Health 10 (8). https://doi.org/10.3390/ijerph10083634

2. Chai SJ, White PL, Lathrop SL, et al. (2012) Salmonella enterica serotype Enteritidis: increasing incidence of domestically acquired infections. Clin Infect Dis; 54(Suppl 5) doi: 10.1093/cid/cis231.

3. Surveillance of seven priority food- and waterborne diseases in the EU/EEA. Stockholm: European Centre for Disease Prevention and Control; 2015 Available by: http://ecdc.europa.eu/en/ publications/Publications/food-and-waterborne-diseasessurveillance-report-2015.pdf, accessed 15 December 2016).

4. Flint J.A., Van Duynhoven Y.T., Angulo F.J. et al (2005) Estimating the burden of acute gastroenteritis, foodborne disease and the pathogens commonly transmitted by food: an international review Clin Infect Dis. 41. doi: 10.1086/432064

5. Hennessy T., Marcus R., Deneen V. (2004) Survey of physician diagnostic practices for patients with acute diarrhea: clinical and public health implications Clin Infect Dis. 38 (3). doi: 10.1086/381588

6. Sydorchuk A.S., Venglovs'ka Y.V., Bohachyk N.A., Sorokhan V.D., Grubliak L.V. (2015) Possibility of acute intestinal food-borne infections holiatry: approach with combined pre- and probiotic Actual Infectology 4 (9) Available by: http://dspace.bsmu.edu.ua:8080/xmlui/bitstream/handle/123456789/10147/Sydorchuk .pdf? sequence $=1$

There is no conflicts of interests

Аннотация: Статья посвящена изучению эффективности применения современного пробиотика "Лакто" в комбинации с оральным раствором «Рео» в составе комплексного лечения пацичентов с острыми кишечными инфекциями. Показано клиническую $u$ микробиологическую эффективность «Лакто» как пробиотика, который содержит сахаромицеты и способен корегировать нарушенный микробиоценоз кишечника с первых дней острого кишечного заболевания, вызванного различными возбудителями. «Лакто» $и$ «Рео» может быть рекомендованный в комплексном лечении взрослых пачиентов в случае острого диарейного синдрома.

Ключевые слова: острая кишечная инфекция, лечение, сахаромицеты, «Лакто», «Peo». 